\title{
The results of the analysis of the criteria of therapeutic alliance of patients orthopedic profile of outpatient physical therapy program
}

\author{
Fedorenko S.M., Vitomskyi V.V., Lazarieva O.B., Vitomska M.B. \\ National University of Physical Education and Sport of Ukraine
}

DOI: https://doi.org/10.34142/HSR.2019.05.03.02

\begin{abstract}
Objective: to determine the peculiarities of forming a therapeutic alliance in outpatients with disorders of orthopedic profile after completing a course of physical therapy and their physical therapists depending on the psychotype of patients.

Methods of research: theoretical analysis and generalization of literary sources, method of systematization of scientific information; Working Alliance Inventory questionnaire Form SF Hatcher (WAI). Patients were grouped using the International Classification of Functioning and Disease Types. The obtained results were processed by adequate methods of mathematical statistics. The study involved 113 patients who underwent a course of physical therapy at FESCO Medical Center during 2013-2015.

Results. According to the results of the statistical analysis, patients with irrational attitude to the disease (irrational psychotypes) had significantly lower scores on the eight items of the WAl questionnaire out of twelve, as well as on all three totals. In particular, the "goal» score was significantly better in patients with rational psychotypes: Me $(25 ; 75)$ scores were $14(12.75 ; 15)$ points, versus 12 $(11 ; 14)$ scores among patients with irrational psychotypes $(p<0,01)$. Similarly, the score of the "task" was $15(13 ; 15)$ points against 12 $(11 ; 15)$ points $(p<0.01)$, and the total score of the "bond" points $16(16 ; 17)$ points against $14(13 ; 15)$ points $(p<0.01)$. Thus, it can be stated that the evaluation of the "goal" items showed the lowest results, which were the farthest from the maximum values.

Conclusion. The results obtained and the statistical analysis made it possible to evaluate the different sides of the level of formation of the therapeutic alliance, to identify the strengths and weaknesses and, thus, necessitated the development of ways to improve the union of the patient and the physical therapist.
\end{abstract}

Key words: working alliance, union, understanding, empathy, physical rehabilitation, therapeutic exercises, staff, consumer, quality.

\section{Анотація}

Федоренко С.Н., Вітомський В.В, Лазарєва О.Б., Вітомськая М.В. Результати аналізу критериїв терапевтичного альянсу пацієнтів ортопедичного профілю амбулаторної програми фізичної терапії

Мета: визначити особливості формування терапевтичного альянсу у амбулаторних пацієнтів з порушеннями ортопедичного профілю після проходження курсу фізичної терапії та їх фізичних терапевтів залежно від психотипу пацієнтів.

Методи дослідження: теоретичний аналіз та узагальнення літературних джерел, метод систематизації наукової інформації; опитувальник Working Alliance Inventory форма SF Hatcher (Оцінка робочого альянсу, WAI). Групування пацієнтів відбувалося 3 використанням Міжнародної класифікації функціонування та методики визначення типів відношення до хвороби. Отримані результати були опрацьовані адекватними методами математичної статистики. У досліджені взяли участь 113 пацієнтів, котрі проходили күрс фізичної терапії у медичному центрі «ФЕСКО» впродовж 2013-2015 років.

Результати. Відповідно до результатів статистичного аналізу пацієнти з нераціональним відношенням до хвороби (нераціональні психотипи) мали достовірно нижчі бали за вісьмома пунктами опитувальника WAl з дванадцяти, а також за усіма трьома сумарними показниками. Зокрема оцінка пунктів «ціль» була достовірно кращою у пацієнтів 3 раціональними психотипами: показники Ме $(25,75)$ становили $14(12,75 ; 15)$ балів, проти $12(11 ; 14)$ балів серед пацієнтів $з$ нераціональними психотипами $(p<0,01)$. Аналогічно оцінка пунктів «завдання» становили $15(13 ; 15)$ балів проти $12(11 ; 15)$ балів $(p<0,01)$, а сумарний показник пунктів «взаємовідносини» - $16(16 ; 17)$ балів проти $14(13 ; 15)$ балів (р<0.01). Таким чином, можна констатувати, що за оцінкою пунктів «ціль» спостерігалися найнижчі результати, котрі були найбільш віддалені від максимальних значень.

Висновок. Отримані результати та проведений статистичний аналіз дозволили оцінити різні сторони рівня формування терапевтичного альянсу, визначити сильніші та слабші місця й, у такий спосіб, обумовили необхідність розробки шляхів покращення союзу пацієнта та фізичного терапевта.

Ключові слова: робочий альянс, союз, розуміння, емпатія, фізична реабілітація, терапевтичні вправи, персонал, споживач, якість.

\footnotetext{
Аннотация

Федоренко С.Н., Витомский В.В, Лазарева Е.Б., Витомская М.В. Результаты анализа критериев терапевтического альянса пациентов ортопедического профиля амбулаторной программы физической терапии

Цель: определить особенности формирования терапевтического альянса у амбулаторных пациентов с нарушениями ортопедического профиля после прохождения курса физической терапии и их физических терапевтов в зависимости от психотипа пациентов.

Методы исследования: теоретический анализ и обобщение литературных источников, метод систематизации научной информации; опросник Working Alliance Inventory форма SF Hatcher (Оценка рабочего альянса, WAI). Группировка пациентов происходила с использованием Международной классификации функционирования и методики определения типов отношения к болезни. Полученные результаты были обработаны адекватными методами математической статистики. В исследовании приняли участие 113 пациентов, проходивших курс физической терапии в медицинском центре «ФЕСКО» В течение 2013-2015 годов.

Результаты. Согласно результатам статистического анализа пациенты с нерациональным отношением к болезни (нерациональные психотипы) имели достоверно ниже баллы по восьми пунктам опросника WAI из двенадцати, а также по всем трем суммарными показателями. В частности оценка пунктов «цель» была достоверно лучше у пациентов с рациональными психотипами: показатели Мe $(25 ; 75)$ составили $14(12,75 ; 15)$ баллов, против $12(11 ; 14)$ баллов среди пациентов с нерациональными психотипами $(\mathrm{p}<0,01)$. Аналогично оценка пунктов «задачи» составила 15 (13; 15) баллов против 12 (11; 15$)$ баллов ( $<0,01)$, а суммарный показатель пунктов «взаимоотношения» 16 (16; 17) баллов против $14(13 ; 15)$ баллов (p<0.01). Таким образом, можно констатировать, что по оценке пунктов «цель» наблюдались низкие результаты, которые были наиболее удалены от максимальных значений.

Вывод. Полученные результаты и проведенный статистический анализ позволили оценить различные стороны уровня формирования терапевтического альянса, определить сильные и слабые места и, таким образом, обусловили необходимость разработки путей улучшения союза пациента и физического терапевта.

Ключевые слова: рабочий альянс, союз, понимание, эмпатия, физическая реабилитация, терапевтические упражнения,
} персонал, потребитель, качество. 


\section{Introduction}

The understanding and communication of the physical therapist with the patients are very important factors that affect the performance. With a sufficient level of communication, the patient's trust in the specialist grows, and over time, a special kind of interaction and relationship is formed by the therapeutic alliance.

The interest in the therapeutic alliance between the clinician and the patient arose in the fields of medical care [1] and psychotherapy [2, 3]. The therapeutic alliance, also referred to in the literature as a working union, therapeutic relationship, or assisting alliance, is a general construction that includes, in its theoretical definition, a collaborative nature, an affective relationship, and an agreement about the purpose and objectives between patients and clinicians [3]. Other constructs, such as trust [4] and empathy [5], may overlap with this definition and are also used to assess alliance quality. This concept is also considered in the field of physical rehabilitation and physical therapy $[6,7,8]$.

Currently, evidence of the importance and necessity of such an alliance in achieving a positive result of physical therapy is being accumulated $[7,8$, 9]. However, there are already results, courts suggest that for those involved in physical therapy for chronic musculoskeletal pain, having a good therapeutic alliance (physical patient therapist) can improve the outcomes of the intervention. In order to facilitate the formation of a strong therapeutic alliance, physical therapists must understand the factors that positively and negatively affect relationships. Studies show that the definition of therapeutic alliance remains unchanged as it moves to traditional settings in the field of physical therapy [7].

Objective: to determine the peculiarities of forming a therapeutic alliance in outpatients with disorders of orthopedic profile after undergoing physical therapy and their physical therapists, depending on the psychotype of patients.

\section{Material and methods}

\section{Participants}

The study involved 113 patients who underwent a course of physical therapy at FESCO Medical Center during 2013-2015.

\section{Procedure}

Theoretical analysis and generalization of literary sources, method of systematization of scientific information. The Working Alliance Inventory (WAI) questionnaire was used to assess the level of therapeutic alliance formation. In general, the questionnaire was designed to evaluate the elements of work collaboration in all forms of relationship related through $[1,11]$. The patient was using the SF Hatcher Client form, which consists of 12 questions. These questions are divided into three groups: goal items; task items; bond items.

SF Hatcher Therapist, which consists of 10 questions, was used for specialists (physical therapists).

A 5-point Likert scale is used for each question, ranging from 1 (rarely) to 5 (always). Accordingly, the maximum score in patient groups is 20 points.

A higher score corresponds to a better score.

Patients were grouped using the International Classification of Functioning (ICF).

The methodology for determining types of attitudes towards illness was used to test views on the presence of the influence of the patient's personality on the effectiveness of treatment, rehabilitation and satisfaction with them [12]. Thus, illness was the second factor in grouping patients.

The obtained results were processed by adequate methods of mathematical statistics.

\section{Results}

According to the results of the use of ICF, it was determined that patients should be grouped according to their affected structure. Thus, G1 included patients with the following ICF codes: $\mathrm{s} 740$ pelvic girdle structure; s750 lower extremity structure; s760 trunk structure. G2 included patients with ICF codes: s710 head and neck structure; s720 shoulder girdle structure; s730 upper limb structure.

The decision of this section and grouping is also justified by the fact that in accordance with the component ICF function in all patients similar codes were noted. In particular b710 joint mobility function; b715 joint stability function; b730 muscle strength function; b735 muscle tone function; b740 muscular endurance function. However, only G1 patients were characterized by the b770 code of the walking stereotype function.

When considering the activities and participation, namely the sections mobility, self-care, home life, it was concluded that for most types of activities requires the participation of both the waist 
and the upper extremity, as well as the trunk, pelvis and lower extremity. Therefore, the possible differences between the groups should be examined more carefully.

Considering these views on grouping patients, it should be noted that 55 patients were affected by $\mathrm{G} 1$ and 58 patients by G1.

The methodology for determining types of attitudes towards illness was used to test views on the presence of the influence of the patient's personality on the effectiveness of treatment, rehabilitation and satisfaction with them [12].

According to the literature data [13, 14], namely regarding the classification of the harmonic, ergopathic and anosognostic types of reaction as "rational", the total sample was divided into group G $+(\mathrm{n}=58$, rational types of disease response $)$ and group $\mathrm{G}-(\mathrm{n}=55$, not rational), and G1 and G2 into subgroups according to psychotypes. Thus, G1 + and $\mathrm{G} 2+$ included rational types of disease response. In particular, G1 + included 28 patients ( $50.9 \%$ of G1), and $\mathrm{G} 2$ + included 30 patients (51.7\% of G2). Other types of patients were included in G1- and G2-.

Given that no significant differences were found between indicators when comparing the G1 + groups with G2 + and G1- with G2, the analysis of therapeutic alliance estimates is presented as a comparison of the $\mathrm{G}+$ and $\mathrm{D}$ groups.

Consider the results of the statistical analysis of the assessment of therapeutic alliance from the patient (table. 1).

Thus, according to the first item of the questionnaire, which is responsible for understanding the patient as to how he or she may change as a result of the lessons, a statistical advantage was noted in patients with a rational psychotype (Table 1). In particular, in $\mathrm{G}+$ the indicators of $\mathrm{Me}(25 ; 75)$ were $4(3 ; 4)$ points and in $\mathrm{G}+$ were $3(3 ; 4)$ points $(\mathrm{p}<0.01)$. The difference of mean values was 0.59 points. Note that the maximum and best score is 5 points.

The next item in the questionnaire is responsible for the frequency of new ways of addressing a patient's problem as a result of what the patient is doing in therapy. Thus, $\operatorname{Me}(25 ; 75)$ indices were $3(3 ; 3)$ points in $\mathrm{G}+$ and $\mathrm{G}-(\mathrm{p}>0.05)$. The difference between the averages was 0.11 points. Note that the maximum and best score is 5 points.

The third point reflects the fact that the patient believes that he or she likes the physical therapist. Among $\mathrm{G}+$ patients, Me $(25 ; 75)$ scores were $4(4 ; 4)$ points, and those in $\mathrm{G}-$ were $3(3 ; 4)$ points ( $p<0.01)$. The difference of mean values was 0.69 points. In this way, patients with rational psychotypes were more likely to like the physical therapist (Table 1).
The fourth item of the questionnaire assessing the collaboration between the physical therapist and the patient in establishing the goals of therapy had slightly lower scores. In particular, in $\mathrm{G}$ + the indicators of $\mathrm{Me}(25 ; 75)$ were $2(2 ; 3)$ points, and in $\mathrm{G}+$ were $2(2 ; 2)$ points $(\mathrm{p}<0.01)$. The difference between the averages was 0.3 points. Thus, both groups had lower than average scores on a 5-point scale.

The level of mutual respect between the patient and the physical therapist is indicated in the fifth item of the questionnaire. In particular, in $\mathrm{G}+$ the indicators of $\mathrm{Me}(25 ; 75)$ were $4(4 ; 5)$ points, and in $\mathrm{G}+$ were $4(3 ; 4)$ points $(\mathrm{p}<0.01)$. The difference of the mean values was 0.56 points. Thus, both groups had higher than average scores on a 5-point scale.

Assessment of the joint work of the physical therapist and the patient towards mutually agreed goals is presented in item 6 of the questionnaire. Thus, Me $(25 ; 75)$ scores were $4(3 ; 4)$ in $\mathrm{G}+$ and 3 $(3 ; 4)$ among G- patients $(\mathrm{p}<0.01)$. The difference of the mean values was 0.33 points.

According to the seventh item of the questionnaire, which is responsible for feeling in the patient that he or she is valued by a physical therapist, a statistical advantage was noted in patients with a rational psychotype. In particular, in $\mathrm{G}+$ the $\mathrm{Me}(25$; $75)$ indicators were $4(4 ; 4)$ points, and in $G+$ were 3 $(3 ; 4)$ points $(\mathrm{p}<0.01)$. The difference of the mean values was 0.71 points. In this way, patients with rational psychotypes had a greater sense of being valued by a physical therapist.

The next item in the questionnaire is responsible for jointly agreeing with the physical therapist and the patient that the patient needs to work on themselves. Thus, $\mathrm{Me}(25 ; 75)$ scores were $4(4 ; 4)$ points in $\mathrm{G}+$ and $\mathrm{G}-$, and the significance of differences between groups was not confirmed ( $p>$ 0.05 ). The difference of mean values was 0.15 points.

The ninth point reflects the fact that the patient feels self-care by the physical therapist, even when the patient does what the physical therapist does not approve of. Among the $\mathrm{G}+$ patients, $\mathrm{Me}$ $(25 ; 75)$ scores were $4(4 ; 4)$ points, and those of $\mathrm{G}-$ were $4(3 ; 4)$. No statistically significant difference between the groups was obtained ( $p>0.05)$. The difference between the averages was only 0.15 points.

The tenth item of the questionnaire assesses the patient's feeling that working in physical therapy will help him or her make the changes he or she wants. In particular, in $\mathrm{G}+$ the indicators of $\mathrm{Me}(25$; $75)$ were $4(3 ; 4)$ points and in $\mathrm{G}+$ were $3(3 ; 4)$ points $(\mathrm{p}<0.01)$. The difference between the averages was 0.59 points, which is quite significant 
considering the rating system. Thus, both groups had higher than average scores on a 5-point scale.

The level of establishment by the physical therapist and the patient of a good understanding of the changes that would be beneficial to the patient is reflected in the eleventh questionnaire score. In particular, in $\mathrm{G}+$ the $\mathrm{Me}(25 ; 75)$ indices were 4 (3; 4) points and in $\mathrm{G}-3(3 ; 4)$ points, but no statistically significant differences were detected ( $p>0.05)$. The difference of the mean values was 0.17 points.
Assessment of the frequency of the patient's opinion that the correct way to deal with his problem is presented in item 12 of the questionnaire. Thus, $\mathrm{Me}$ $(25 ; 75)$ scores were $4(3 ; 4)$ in $\mathrm{G}+$ and $3(3 ; 4)$ among G- patients $(p<0.01)$. The difference of the mean values was 0.55 points. In this way, patients with rational psychotypes are more likely to believe that the way they deal with their problem is right.

The average indicators of evaluation of therapeutic alliance in patients, points

Table 1

\begin{tabular}{|c|c|c|c|}
\hline \multicolumn{2}{|c|}{ Items } & \multicolumn{2}{|c|}{ Groups } \\
\hline the & & $G+(n=58)$ & $G-(n=55)$ \\
\hline \multirow{2}{*}{1} & $\operatorname{Me}(25 ; 75)$ & $4(3 ; 4)$ & $3(3 ; 4)^{* *}$ \\
\hline & $\overline{\mathrm{x}} \pm \mathrm{S}$ & $3,90 \pm 0,69$ & $3,31 \pm 0,69$ \\
\hline \multirow{2}{*}{2} & $\operatorname{Me}(25 ; 75)$ & $3(3 ; 3)$ & $3(3 ; 3)$ \\
\hline & $\overline{\mathrm{x}} \pm \mathrm{S}$ & $2,93 \pm 0,37$ & $2,82 \pm 0,47$ \\
\hline \multirow{2}{*}{3} & $\operatorname{Me}(25 ; 75)$ & $4(4 ; 4)$ & $3(3 ; 4)^{* *}$ \\
\hline & $\overline{\mathrm{x}} \pm \mathrm{S}$ & $4,07 \pm 0,37$ & $3,38 \pm 0,49$ \\
\hline \multirow{2}{*}{4} & $\mathrm{Me}(25 ; 75)$ & $2(2 ; 3)$ & $2(2 ; 2)^{* *}$ \\
\hline & $\overline{\mathrm{x}} \pm \mathrm{S}$ & $2,43 \pm 0,50$ & $2,13 \pm 0,34$ \\
\hline \multirow{2}{*}{5} & $\mathrm{Me}(25 ; 75)$ & $4(4 ; 5)$ & $4(3 ; 4)^{* *}$ \\
\hline & $\overline{\mathrm{X}} \pm \mathrm{S}$ & $4,21 \pm 0,52$ & $3,65 \pm 0,48$ \\
\hline \multirow{2}{*}{6} & $\mathrm{Me}(25 ; 75)$ & $4(3 ; 4)$ & $3(3 ; 4)^{* *}$ \\
\hline & $\overline{\mathrm{X}} \pm \mathrm{S}$ & $3,71 \pm 0,46$ & $3,38 \pm 0,49$ \\
\hline \multirow{2}{*}{7} & $\operatorname{Me}(25 ; 75)$ & $4(4 ; 4)$ & $3(3 ; 4)^{* *}$ \\
\hline & $\overline{\mathrm{X}} \pm \mathrm{S}$ & $4,07 \pm 0,37$ & $3,36 \pm 0,49$ \\
\hline \multirow{2}{*}{8} & $\mathrm{Me}(25 ; 75)$ & $4(4 ; 4)$ & $4(4 ; 4)$ \\
\hline & $\overline{\mathrm{X}} \pm \mathrm{S}$ & $4,24 \pm 0,43$ & $4,09 \pm 0,40$ \\
\hline \multirow{2}{*}{9} & $\mathrm{Me}(25 ; 75)$ & $4(4 ; 4)$ & $4(3 ; 4)$ \\
\hline & $\overline{\mathrm{x}} \pm \mathrm{S}$ & $4,02 \pm 0,51$ & $3,87 \pm 0,61$ \\
\hline \multirow{2}{*}{10} & $\operatorname{Me}(25 ; 75)$ & $4(3 ; 4)$ & $3(3 ; 4)^{* *}$ \\
\hline & $\overline{\mathrm{X}} \pm \mathrm{S}$ & $3,88 \pm 0,68$ & $3,29 \pm 0,53$ \\
\hline \multirow{2}{*}{11} & $\operatorname{Me}(25 ; 75)$ & $4(3 ; 4)$ & $3(3 ; 4)$ \\
\hline & $\overline{\mathrm{X}} \pm \mathrm{S}$ & $3,55 \pm 0,50$ & $3,38 \pm 0,49$ \\
\hline \multirow{2}{*}{12} & $\operatorname{Me}(25 ; 75)$ & $4(3 ; 4)$ & $3(3 ; 4)^{* *}$ \\
\hline & $\overline{\mathrm{X}} \pm \mathrm{S}$ & $3,84 \pm 0,77$ & $3,29 \pm 0,57$ \\
\hline \multirow{2}{*}{$\begin{array}{c}\text { Assessment of the item } \\
\text { «Goal» }\end{array}$} & $\operatorname{Me}(25 ; 75)$ & $14(12,75 ; 15)$ & $12(12 ; 14)^{* *}$ \\
\hline & $\overline{\mathrm{X}} \pm \mathrm{S}$ & $13,93 \pm 1,39$ & $12,98 \pm 1,28$ \\
\hline \multirow{2}{*}{$\begin{array}{c}\text { Assessment of the item } \\
\text { "Task» }\end{array}$} & $\operatorname{Me}(25 ; 75)$ & $15(13 ; 15)$ & $12(11 ; 15)^{* *}$ \\
\hline & $\overline{\mathrm{X}} \pm \mathrm{S}$ & $14,55 \pm 2,12$ & $12,71 \pm 1,69$ \\
\hline \multirow{2}{*}{$\begin{array}{l}\text { Assessment of the item } \\
\text { «relationship» }\end{array}$} & $\operatorname{Me}(25 ; 75)$ & $16(16 ; 17)$ & $14(13 ; 15)^{* *}$ \\
\hline & $\overline{\mathrm{X}} \pm \mathrm{S}$ & $16,36 \pm 0,97$ & $14,27 \pm 1,10$ \\
\hline
\end{tabular}

The overall score of the "target" items was significantly better in patients with rational psychotypes. Thus, Me $(25 ; 75)$ scores were 14 $(12.75 ; 15)$ in $\mathrm{G}+$ and $12(11 ; 14)$ in $\mathrm{G}-(\mathrm{p}<0.01)$. The difference between the mean values was 0.95 points. Thus, patients with rational psychotypes had an advantage of the arithmetic mean of $7.3 \%$ of the estimate of the group G-.

The following overall assessment of the "task" items was also significantly better in patients with rational psychotypes. Thus, Me $(25 ; 75)$ scores were $15(13 ; 15)$ in $\mathrm{G}+$ and $12(11 ; 15)$ in G- (p 
$<0.01)$ patients. The difference between the averages was 1.84 points. In this way, patients with rational psychotypes had an advantage of the arithmetic mean of $14.5 \%$ of the advantage of the arithmetic mean estimate of the group G-.

The last overall assessment is responsible for the items on the relationship level. This estimate was also significantly better in patients with rational psychotypes. Thus, Me (25; 75) scores were 16 (16; 17) points in $G+$ and $14(13 ; 15)$ points among patients of group $\mathrm{G}-(\mathrm{p}<0.01)$. The difference between the averages was 2.09 points. In this way, patients with rational psychotypes had an advantage of the arithmetic mean of $14.6 \%$ of the estimate of the group G-.

Consider the results of the statistical analysis of the evaluation of the therapeutic alliance by the physical therapist (Table. 2).

The first item of the questionnaire is responsible for the opinion of the physical therapist regarding the patient's joint agreement with the patient on the steps to be taken to improve his / her situation. Thus, Me $(25 ; 75)$ scores were $4(3 ; 4)$ points in $\mathrm{G}+$ and $3(3 ; 4)$ points in $\mathrm{G}_{-}$, and a significant difference between the groups was confirmed $(p<0.01)$. The difference of the mean values was 0.25 points.

The second point reflects the fact that the physical therapist genuinely cares for the well-being of the patient. Among G + and G- patients, Me (25; 75) was $4(4 ; 4)$. No statistically significant difference between the groups was obtained ( $p>0.05)$. The difference between the averages was only 0.1 points.

Assessment of the physical therapist working together with the patient towards mutually agreed goals is presented in the third item of the questionnaire for the specialist. Thus, Me $(25 ; 75)$ indices were $3(3 ; 4)$ points in $\mathrm{G}+$ and $\mathrm{G}-(\mathrm{p}>0.05)$. The difference between the averages was minimal.

The fourth item of the questionnaire assesses the opinion of the physical therapist that he and the patient are confident in the usefulness of our ongoing activity in therapy. In particular, in $\mathrm{G}+$ the indicators of $\mathrm{Me}(25 ; 75)$ were $4(4 ; 4)$ points, and in $\mathrm{G}+$ were $4(3 ; 4)$ points $(\mathrm{p}<0.01)$. The difference between the averages was 0.54 points, which is quite significant considering the rating system. Thus, both groups had higher than average scores on a 5-point scale.

The fifth point reflects the fact that the physical therapist values the patient as an individual.
Among the $\mathrm{G}+$ patients, $\mathrm{Me}(25 ; 75)$ scores were 4 $(4 ; 5)$ points, and those in the $G$ group were $4(4 ; 4)$ points $(\mathrm{p}<0.01)$. The difference of the mean values was 0.29 points. Thus, both groups had statistically high rates. Therefore, patients with rational psychotypes are somewhat more appreciated by experts as a person, perhaps as a result of easier collaboration with them.

The opinion of the physical therapist regarding the level of establishment with the patient of a good understanding of the changes that would be beneficial is reflected in the sixth questionnaire score. In particular, in $\mathrm{G}+$ the $\mathrm{Me}(25 ; 75)$ indices were $4(3 ; 4)$ points and in $\mathrm{G}-3(3 ; 4)$ points, but no statistically significant differences were detected $(p>$ $0.05)$. The difference of mean values was 0.15 points. Thus, both groups had higher than average scores on the 5-point scale, but were far removed from the maximum.

The level of mutual respect between the patient and the physical therapist, according to the latter, is indicated in the seventh item of the specialist questionnaire. In particular, in $\mathrm{G}+$ the indicators of Me $(25 ; 75)$ were $4(4 ; 4)$ points, and in $\mathrm{G}+$ were 4 $(3 ; 4)$ points $(\mathrm{p}<0.01)$. The difference of the mean values was 0.48 points. Thus, both groups had higher than average scores on a 5-point scale.

The eighth item of the questionnaire, assessing the patient's and the physical therapist's overall perception of the patient's goals, had slightly lower scores. In particular, in G + and in G-, the Me $(25 ; 75)$ indices were $3(3 ; 4)$ points $(p>0.05)$.

The next item in the questionnaire is responsible for respecting the patient's physical therapist, even when the patient does what the physical therapist does not approve of. Thus, $\mathrm{Me}(25$; $75)$ scores were $4(4 ; 4)$ points in $\mathrm{G}+$ and $4(3 ; 4)$ points in $\mathrm{G}-(\mathrm{p}>0.05)$. The difference of the mean values was 0.2 points.

The last item of the questionnaire for the specialist is responsible for the joint agreement of the physical therapist and the patient that the patient needs to work on himself. Thus, Me $(25 ; 75)$ scores were $4(4 ; 4)$ points in $\mathrm{G}+$ and $4(3 ; 4)$ points in $(\mathrm{p}$ $<0.01)$. The difference between the averages was 0.35 points.

In addition, in order to check the consistency of the evaluation of the therapeutic alliance, comparisons were made between patient and specialist outcomes by similar items in the questionnaires (Table 3). 
Table 2

Average indicators of evaluation of therapeutic alliance in physical therapists according to patient groups by psychotype, points

\begin{tabular}{|c|c|c|c|}
\hline \multirow{2}{*}{\multicolumn{2}{|c|}{ Items }} & \multicolumn{2}{|c|}{ Groups } \\
\hline & & $G+(n=58)$ & $\mathrm{G}-(\mathrm{n}=55)$ \\
\hline \multirow{2}{*}{1} & $\mathrm{Me}(25 ; 75)$ & $4(3 ; 4)$ & $3(3 ; 4)^{* *}$ \\
\hline & $\overline{\mathrm{X}} \pm S$ & $3,74 \pm 0,44$ & $3,49 \pm 0,50$ \\
\hline \multirow{2}{*}{2} & $\operatorname{Me}(25 ; 75)$ & $4(4 ; 4)$ & $4(4 ; 4)$ \\
\hline & $\overline{\mathrm{X}} \pm \mathrm{S}$ & $4,14 \pm 0,35$ & $4,04 \pm 0,19$ \\
\hline \multirow{2}{*}{3} & $\operatorname{Me}(25 ; 75)$ & $3(3 ; 4)$ & $3(3 ; 4)$ \\
\hline & $\overline{\mathrm{X}} \pm \mathrm{S}$ & $3,36 \pm 0,48$ & $3,35 \pm 0,48$ \\
\hline \multirow{2}{*}{4} & $\mathrm{Me}(25 ; 75)$ & $4(4 ; 4)$ & $4(3 ; 4)^{* *}$ \\
\hline & $\overline{\mathrm{X}} \pm \mathrm{S}$ & $4,10 \pm 0,48$ & $3,56 \pm 0,50$ \\
\hline \multirow{2}{*}{5} & $\mathrm{Me}(25 ; 75)$ & $4(4 ; 5)$ & $4(4 ; 4)^{* *}$ \\
\hline & $\overline{\mathrm{X}} \pm \mathrm{S}$ & $4,38 \pm 0,56$ & $4,09 \pm 0,29$ \\
\hline \multirow{2}{*}{6} & $\operatorname{Me}(25 ; 75)$ & $4(3 ; 4)$ & $3(3 ; 4)$ \\
\hline & $\overline{\mathrm{X}} \pm \mathrm{S}$ & $3,59 \pm 0,50$ & $3,44 \pm 0,50$ \\
\hline \multirow{2}{*}{7} & $\operatorname{Me}(25 ; 75)$ & $4(4 ; 4)$ & $4(3 ; 4) * *$ \\
\hline & $\overline{\mathrm{X}} \pm \mathrm{S}$ & $4,17 \pm 0,46$ & $3,69 \pm 0,63$ \\
\hline \multirow{2}{*}{8} & $\operatorname{Me}(25 ; 75)$ & $3(3 ; 4)$ & $3(3 ; 4)$ \\
\hline & $\overline{\mathrm{X}} \pm \mathrm{S}$ & $3,40 \pm 0,49$ & $3,38 \pm 0,49$ \\
\hline \multirow{2}{*}{9} & $\operatorname{Me}(25 ; 75)$ & $4(4 ; 4)$ & $4(3 ; 4)$ \\
\hline & $\overline{\mathrm{X}} \pm \mathrm{S}$ & $3,93 \pm 0,53$ & $3,73 \pm 0,68$ \\
\hline \multirow{2}{*}{10} & $\operatorname{Me}(25 ; 75)$ & $4(4 ; 4)$ & $4(3 ; 4) * *$ \\
\hline & $\overline{\mathrm{X}} \pm \mathrm{S}$ & $4,10 \pm 0,31$ & $3,75 \pm 0,44$ \\
\hline
\end{tabular}

Note. ${ }^{*}$ - the difference between group indices is statistically significant $p<0,05 ; * *-p<0.01$

Table 3

Results of Comparison of Experts and Patients' Assessments by Therapeutic Alliance Questionnaire

\begin{tabular}{|c|c|c|c|c|c|c|c|c|}
\hline $\begin{array}{c}\text { Items, } \\
\text { specialist }\end{array}$ & $\begin{array}{l}\text { Items, } \\
\text { patient }\end{array}$ & G & $\mathrm{G}+$ & G- & G1+ & G1- & G2+ & G2- \\
\hline 1 & 11 & $\mathrm{p}=0,00^{*}$ & $\mathrm{p}=0,03^{*}$ & $p>0,05$ & $\mathrm{p}=0,03^{*}$ & $p>0,05$ & $p>0,05$ & $p>0,05$ \\
\hline 3 & 6 & $p=0,00$ & $p=0,00$ & $p>0,05$ & $p=0,00$ & $p>0,05$ & $p=0,00$ & $p>0,05$ \\
\hline 4 & 10 & $p=0,00^{*}$ & $\mathrm{p}=0,00^{*}$ & $\mathrm{p}=0,00^{*}$ & $p>0,05$ & $p>0,05$ & $p=0,03^{*}$ & $\mathrm{p}=0,00^{*}$ \\
\hline 5 & 7 & $p=0,00^{*}$ & $\mathrm{p}=0,00^{*}$ & $\mathrm{p}=0,00^{*}$ & $\mathrm{p}=0,00^{*}$ & $\mathrm{p}=0,00^{*}$ & $\mathrm{p}=0,05^{*}$ & $\mathrm{p}=0,00^{*}$ \\
\hline 6 & 11 & $p>0,05$ & $p>0,05$ & $p>0,05$ & $p>0,05$ & $p>0,05$ & $p>0,05$ & $p>0,05$ \\
\hline 7 & 5 & $p>0,05$ & $p>0,05$ & $p>0,05$ & $p>0,05$ & $p>0,05$ & $p>0,05$ & $p>0,05$ \\
\hline 9 & 9 & $p=0,00$ & $p>0,05$ & $p=0,02$ & $p>0,05$ & $p>0,05$ & $p>0,05$ & $p=0,02$ \\
\hline 10 & 8 & $p=0,00$ & $p=0,00$ & $p=0,00$ & $p=0,04$ & $p=0,00$ & $p=0,04$ & $p=0,00$ \\
\hline
\end{tabular}

\section{Discussion}

Taking into account that, according to the general estimates of the patient questionnaire, the maximum score is 20 , it is possible to calculate what percentage of the maximum received groups by these three indicators. In this way, the following indicators were obtained by evaluating goal items: for patients $\mathrm{G}+69.7 \%$ of the maximum score, and for $\mathrm{G}-64.9 \%$. The overall indicator for task items was $72.8 \%$ and $63.6 \%$ of the maximum score respectively. In this calculation, the overall average rating of bond items in the groups had the biggest difference: among patients $\mathrm{G}+81.8 \%$ of the maximum score, and in $\mathrm{G}$ $-71.4 \%$.

Thus, it can be stated that the evaluation of the "goal" items showed the lowest results, which were the farthest from the maximum values. Somewhat better were the scores on the score of the "task". That is, these points need to be taken to improve the indicators of the therapeutic alliance and the physical therapy system as a whole. And in order 
to reduce the sufficiently pronounced difference between $\mathrm{G}+$ and $\mathrm{D}$ - in the assessment of "relationship" points, measures should also be taken to improve the relationship with patients with irrational psychotypes.

Therefore, of all points of the specialist questionnaire, only five and only the upper quartile were presented with five points, which indicates that the physical therapist could be better involved in the process, according to the analysis of the results of the questionnaire.

According to the results presented in Table 3 , it can be stated that a couple of paragraphs 3-6 on "working towards mutually agreed goals" had significant benefits for patients in groups with rational psychotypes and overall sampling. The pairs of items 4-10 (assessment of the utility of current therapy in achieving change) and 5-7 ("appreciation of the patient as an individual") had many significant benefits for the benefit of physical therapists in the groups.

The point of agreeing on the need to work on yourself was also better appreciated by patients. The opposite can be interpreted as the desire of the physical therapist for the patient to work more on himself; or a patient reassessing their work on themselves.

The results of our work supplemented the data on the formation of a therapeutic alliance between patients and physical therapists.

In particular, Lawford B. [9] investigated the therapeutic alliance between physical therapists and patients with knee osteoarthritis during telephone consultations using the Working Alliance Inventory (Short Form). Three aspects were studied: describing and comparing the assessments of the physical therapist and the patient; determine if the alliance changes over time; evaluate the relationship of certain characteristics to the alliance. Patients received 5-10 consultations with one in 8 physiotherapists over the phone, including aspects of education, counseling, and prescribing a strengthening and exercise program. The therapeutic alliance was measured after the second (4 weeks) and last consultation ( 26 weeks). The authors state that the ratings of patients and physiotherapists were high. At 4 weeks, patients rated the alliance and all three subscales were higher than therapists. At 26 weeks, patients rated the task items higher than therapists. Patients 'scores for the goal items subscale declined over time, while physical therapists' scores on the general alliance scale and the relationship scale increased. Therapists were more likely to form a stronger alliance if they had less clinical experience and the treatment of younger patients and those with higher self-efficacy.
At the same time, we supplemented the data on factors that influence the level of therapeutic alliance, namely the type of patient's attitude to the disease. The literature has referred to the identification of a number of factors that influence the alliance between a patient and a physical therapist [7].

The impact of therapeutic alliance between patients and physical therapists on treatment outcome in the rehabilitation of patients with chronic low back pain was investigated by Ferreira P.H. and co-authors [15]. An evaluation conducted with the Working Alliance Inventory showed that the therapeutic alliance was a predictor of performance, overall treatment, pain, and disability effects. however, it should be noted that these indicators were evaluated before and after 8 weeks of treatment, and the therapeutic alliance was evaluated at the second treatment session, which may have prejudiced the interaction during the initial stages of treatment.

A literature review of studies on the effects of the therapeutic alliance on low back pain conducted by Taccolini Manzoni A.C. and coauthors [8], found that stimulating measures to form a therapeutic alliance during treatment contribute to a significant improvement in pain; studies without stimulus measures have shown differences in the relationship between therapeutic alliance and pain. Existing studies have shown that there is no evidence of a strong link between the therapeutic alliance and pain relief.

At the same time, an earlier literature review [6] noted the existence of significant positive associations between the alliance and a number of indicators in patients with musculoskeletal disorders. In particular, researchers have found work to confirm the impact of the therapeutic alliance on the global perceived effect of physical therapy $[16,17,18]$, change in pain $[19,18]$, physical function $[16,20]$, patient satisfaction with treatment [21], depression, and general health [19].

In this way, the relevance of the developments to improve the formation of the therapeutic alliance, to improve the motivation of patients and staff, to identify ways to improve the quality of physical therapy services is confirmed. In particular, recent articles have been published in this direction [22, 23] and further work is underway.

In the same aspect, it should be noted that communication skills that contribute to improving the therapeutic alliance can be taught $[24,25,26]$.

\section{Conclusion}

The therapeutic alliance is an interesting and relevant subject of study in the field of physical 
therapy of patients with orthopedic profile at the outpatient stage.

According to the results of the statistical analysis, patients with irrational illness (irrational psychotypes) had significantly lower scores on the eight items of the questionnaire out of twelve, as well as on all three total indicators. The results of the analysis of the version of the questionnaire for specialists also confirmed the presence of a worse therapeutic alliance when dealing with patients with irrational treatment of the disease. Thus, the experts of patients with irrational psychotypes rated the therapeutic alliance statistically worse by five items of the questionnaire for specialists out of ten.

The results obtained and the statistical analysis made it possible to evaluate the different sides of the level of formation of the therapeutic alliance, to identify the strengths and weaknesses and, thus, necessitated the development of ways to improve the union of the patient and the physical therapist.

\section{Acknowledgments}

The work was carried out in accordance with the plan of research and development of the NFVSU for 2016-2020 on the topic: 4.2. "Organizational and theoretical and methodological foundations of physical rehabilitation of persons of different nosological, professional and age groups", State Registration Number 0116U001609.

\section{Conflict of interest}

The authors state no conflict of interest.

\section{References}

1. Stewart MA. Effective physician-patient communication and health outcomes: a review. CMAJ: Canadian Medical Association Journal. 1995 May 1;152(9):1423.

2. Horvath AO, Symonds BD. Relation between working alliance and outcome in psychotherapy: A metaanalysis. Journal of counseling psychology. 1991 Apr;38(2):139.

3. Martin DJ, Garske JP, Davis MK. Relation of the therapeutic alliance with outcome and other variables: a meta-analytic review. Journal of consulting and clinical psychology. 2000 Jun;68(3):438.

4. Hall MA, Zheng B, Dugan E, Camacho F, Kidd KE, Mishra A, Balkrishnan R. Measuring patients' trust in their primary care providers. Medical care research and review. 2002 Sep;59(3):293-318.

5. Mercer SW, Maxwell M, Heaney D, Watt G. The consultation and relational empathy (CARE) measure: development and preliminary validation and reliability of an empathy-based consultation process measure. Family practice. 2004 Dec 1;21(6):699-705.

6. Hall AM, Ferreira PH, Maher CG, Latimer J, Ferreira ML. The influence of the therapist-patient relationship on treatment outcome in physical rehabilitation: a systematic review. Physical therapy. 2010 Aug 1;90(8):1099-110.

7. Kinney M, Seider J, Beaty AF, Coughlin K, Dyal M, Clewley D. The impact of therapeutic alliance in physical therapy for chronic musculoskeletal pain: A systematic review of the literature. Physiother Theory Pract. 2018;28:1-13.

8. Taccolini Manzoni AC, Bastos de Oliveira NT, Nunes Cabral CM, Aquaroni Ricci N. The role of the therapeutic alliance on pain relief in musculoskeletal rehabilitation: A systematic review. Physiotherapy theory and practice. 2018;34(12):901-15.

9. Lawford B, Bennell KL, Campbell PK, Kasza J, Hinman RS. Therapeutic alliance between physiotherapists and patients with knee osteoarthritis consulting via telephone: a longitudinal study. Arthritis Care \& Research. 2019. doi: 10.1002/acr.23890.

10. Horvath AO. Empirical validation of Bordin's pan theoretical model of the alliance: The Working Alliance Inventory perspective. In A. O. Horvath \& $L$. S. Greenberg (Eds.), The working alliance: Theory, research and practice. New York: Wiley; 1994. pp. 109-130.

11. Munder T, Wilmers F, Leonhart R, Linster HW, Barth J. Working Alliance Inventory-Short Revised (WAISR): psychometric properties in outpatients and inpatients. Clinical psychology \& psychotherapy. 2010;17(3):231-9..

12. Shcherbakova AM, Goodilina OH. Comparative characteristics of the attitude to the limited possibilities of their health for persons with congenital and acquired disorders of statodynamic function. Psychological Science and Education. 2010;5:77-86. (in Russian)

13. Kalashnikov ON. Aspects of the interaction between the patient and the doctor, the possibility of their optimization in medical practice (Part 2). Therapia 2015 [cited 2016 January 21]; 7-8 (100). Available: http://therapia.ua/therapia/2015-/7-8-100/aspektyvzaimodeistviya-patsienta-i-vracha-vozmozhnost-ikhoptimizatsii-v-meditsinskoi-praktike-chast-2. (in Russian)

14. Chernov A. 12 patients and their psychotypes. Katrenstyle [Internet]. 2013 [cited 2016 January 21]; 122. Available: https:// https://www.katrenstyle.ru/articles/journal/medicine/e thics/12_patsientov_i_ih_psihotipyi. (in Russian)

15. Ferreira PH, Ferreira ML, Maher CG, Refshauge KM, Latimer J, Adams RD. The therapeutic alliance between clinicians and patients predicts outcome in chronic low back pain. Physical therapy. 2013 Apr 1;93(4):470-8.

16. Ferreira PH, Ferreira ML, Maher CG, Refshauge KM, Latimer J, Adams RD. The therapeutic alliance 
between physiotherapists and patients predicts outcome in chronic low back pain. In: International Forum X Primary Care Research on Low Back Pain; June 13-17, 2009; Boston, Massachusetts. 2009:131.

17. Zaproudina N, Hanninen OO, Airaksinen O. Effectiveness of traditional bone setting in chronic neck pain: randomized clinical trial. J Manipulative Physiol Ther. 2007; 30:432- 437.

18. Zaproudina N, Hietikko T, Hanninen OO, Airaksinen $\mathrm{O}$. Effectiveness of traditional bone setting in treating chronic low back pain: a randomised pilot trial. Complement Ther Med. 2009;17:23-28.

19. Mirsky J. Anger expression, working alliance, and treatment outcome following multidisciplinary chronic pain treatment. In: Illinois Institute of Technology. Chicago, IL: Illinois Institute of Technology; 2002:118.

20. Higdon L. Patient Hostility, the Working Alliance, and Treatment Outcome in a Work Hardening Center. Chicago, IL: The Herman M. Finch University of Health Sciences, The Chicago Medical School; 1997: 120.

21. Beattie P, Turner C, Dowda M, Michener L, Nelson R. The MedRisk Instrument for Measuring Patient Satisfaction With Physical Therapy Care: a psychometric analysis. J Orthop Sports Phys Ther. 2005;35:24 -32.

22. Vitomskyi VV, Lazarieva OB, Fedorenko SM, Vitomska MV. Methods of management and motivation in personnel management of the center of physical therapy and improving the quality of services for patients with orthopedic profile at the outpatient stage. Health, sport, rehabilitation. 2019;2:17-27. DOI: https://doi.org/10.34142/HSR.2019.05.01.02.02.

23. Fedorenko S, Vitomskyi V, Lazarieva O, Vitomska M. Management and Motivation of Patients as a Way of Increasing the Efficiency of Physical Therapy in Orthopedic Disorders. JMBS 2019, 4(5): 295-302. DOI: $10.26693 / j m b s 04.05 .295$. (in Ukrainian)

24. Lewin S, Skea Z, Entwistle VA, Zwarenstein M, Dick J. Interventions for providers to promote a patientcentred approach in clinical consultations. Cochrane database of systematic reviews. 2001(4).

25. McGilton KS, Boscart V, Fox M, Sidani S, Rochon E, Sorin-Peters R. A systematic review of the effectiveness of communication interventions for health care providers caring for patients in residential care settings. Worldviews on Evidence-Based Nursing. 2009 Sep;6(3):149-59.

26. Moore PM, Wilkinson SS, Mercado SR. Communication skills training for health care professionals working with cancer patients, their families and/or carers. Cochrane Database of Systematic Reviews. 2004(2).

\section{Information about the authors}

\section{Інформація про авторів}

\section{Fedorenko S.M.}

fesco_klinik@ukr.net

https://orcid.org/0000-0002-6266-5361

National University of Physical Education and Sport of Ukraine

Phyzkul'tury str. 1, Kyiv, 03680, Ukraine.

\section{Vitomskyi V.V.}

vitomskiyvova@rambler.ru

https://orcid.org/0000-0002-4582-6004

National University of Physical Education and Sport of Ukraine

Phizkultury Street, 1, Kiev, 03680, Ukraine.

\section{Lazarieva O.B.}

helenka1972@gmail.com

https://orcid.org/0000-0002-7435-2127.

National University of Physical Education and Sport of Ukraine

Phyzkul'tury str. 1, Kyiv, 03680, Ukraine.

\section{Vitomska M.V.}

marinavitomskaya@gmail.com

https://orcid.org/0000-0002-5163-3954

National University of Physical Education and Sport of

Ukraine

Phyzkul'tury str. 1, Kyiv, Kiev, 03680, Ukraine.

Федоренко С.М.

fescoklinik@ukr.net

https://orcid.org/0000-0002-6266-5361

Національний університет фізичного виховання і спорту України

вул.Фізкультури, 1, Київ, 03680,Україна.

\section{Вітомський В. В.}

vitomskiyvova@rambler.ru

https://orcid.org/0000-0002-4582-6004

Національний університет фізичного виховання i спорту України

вул. Фізкультури, 1, Київ, 03680,Україна.

Лазарєва О. Б.

helenka1972@gmail.com

https://orcid.org/0000-0002-7435-2127

Національний університет фізичного виховання $\mathrm{i}$ спорту України

вул. Фізкультури, 1, Київ, 03680, Україна.

\section{Вітомська М. В.}

marinavitomskaya@gmail.com

https://orcid.org/0000-0002-5163-3954

Національний університет фізичного виховання і спорту України

вул.Фізкультури, 1, Київ, 03680,Україна

Принята в редакцฺию: 16.08.2019 